\title{
Study on the Bathroom Space and the Application of Same-Floor Drainage in Congregate Housing
}

\author{
Wan-Ju Liao ${ }^{1, * \mathbb{D}}$, Cheng-Li Cheng ${ }^{2} \mathbb{D}$ and Chao-Jung Lee ${ }^{2}$ \\ 1 Department of Construction Engineering, National Kaohsiung University of Science and Technology, \\ Kaohsiung 824005, Taiwan \\ 2 Department of Architecture, National Taiwan University of Science and Technology, Taipei 10672, Taiwan; \\ CCL@mail.ntust.edu.tw (C.-L.C.); m10713008@gapps.ntust.edu.tw (C.-J.L.) \\ * Correspondence: liaowj@nkust.edu.tw
}

check for updates

Citation: Liao, W.-J.; Cheng, C.-L.; Lee, C.-J. Study on the Bathroom Space and the Application of Same-Floor Drainage in Congregate Housing. Water 2021, 13, 2922. https:/ / doi.org/10.3390/w13202922

Academic Editor:

Francesco Napolitano

Received: 15 August 2021

Accepted: 14 October 2021

Published: 17 October 2021

Publisher's Note: MDPI stays neutral with regard to jurisdictional claims in published maps and institutional affiliations.

Copyright: (c) 2021 by the authors. Licensee MDPI, Basel, Switzerland. This article is an open access article distributed under the terms and conditions of the Creative Commons Attribution (CC BY) license (https:// creativecommons.org/licenses/by/ $4.0 /)$.

\begin{abstract}
There are no regulations in Taiwan that clearly forbid the current practice of configuring a pipeline that passes through the floor of a condo to reach the ceiling of another condo downstairs with different ownership, giving rise to potential disputes during pipeline maintenance. In Japan and China, the regulations for water supply and the drainage system strictly forbid the installation of drainage pipes that pass through the floor of a condo to reach the ceiling of another condo downstairs. In this study, life cycle cost analysis was adopted to investigate the traditional piping system as well as the same-floor drainage system, including the descended floor piping system, the raised floor piping system and a pre-wall piping system. According to the results of the life cycle cost and benefit analysis for pipeline renewal and maintenance, and taking into account the overall pipeline construction cost, although adoption of the same-floor drainage system increases the total cost by about $0.3-2.7 \%$, it shows benefits in terms of pipeline maintenance and construction time. From the perspective of property management, if the same-floor drainage system can be implemented in the initial design stage, operation and management related issues can be minimized to reduce both pipeline maintenance and management costs, achieving the best performance in sustainable construction and maintenance.
\end{abstract}

Keywords: same-floor drainage; life cycle cost; building drainage system

\section{Introduction}

Building a drainage system is critical to home sanitation. It relies on the correct drainage pipeline configuration to fulfill the purpose of health and safety [1-3]. In general, the life cycle of a drainage system in congregate housing is much shorter than that of building structures, which has an average service life of about 15 years [4]. To allow drainage systems to run smoothly, frequent renovation and maintenance are often required [5-7]. The outbreak of SARS in the Amoy Gardens, a large residential community in Hong Kong, was due to the breaking of the house trap seal, leading to the rapid spread of virus throughout the community via the venting pipeline [8-10]. Since this incident, people started to pay more attention to the performance and safety of drainage systems in buildings [11-13].

In Taiwan's traditional building drainage systems, the floor-penetrating piping system is often adopted, since it is relatively simple and easy to implement [14]. However, such methods may lead to issues, such as water leakage, pipeline blockage and noise, with water leakage being the most serious problem [15]. For congregated housing, the application of this type of piping system, with drainage pipes penetrating through the floor of a condo to reach the ceiling of another condo downstairs, causes not only inconvenience in pipeline maintenance but also potential ownership disputes. Moreover, the application of such methods to congregate housing also infringes on the ownership of other households [16,17]. According to data from the literature, $67.62 \%$ of the pipeline in domestic buildings is still based on an embedded piping system, meaning that the pipeline is buried in the 
structure [18]. This may cause issues such as pipeline rust, accumulation of filth over time or difficulty in identifying and repairing problematic pipes. On the other hand, $58 \%$ of people in residential buildings have experienced pipeline leakage or blockage problems, and more than $15 \%$ of people have had drainage pipeline blockage or water leakage problems more than four times [19]. Taking Japan and China as examples [20-22], in the SI Housing Guidelines as well as the regulations for the same-floor drainage system of building, there are clear specifications indicating that the drainage pipeline must not pass through the floor of a condo to reach the ceiling of another condo downstairs, in order to facilitate the maintenance and management of the building throughout its life cycle.

Taiwan's regulations on the design and performance of water supply and drainage systems for buildings are generally appropriate and complete. In recent years, some of the drainage systems in congregate housing have adopted the same-floor drainage system to fulfill the idea of sustainable operation and maintenance throughout the entire life cycle of the building. For this reason, this study first understands the current practice of same-floor drainage for buildings in Taiwan. Furthermore, life cycle cost net present value analysis is adopted to investigate the cost and benefit between the same-floor drainage system and the traditional piping system. In addition, cases of actual buildings are introduced for discussion, serving as a reference for planning the design and cost of the same-floor drainage System for buildings in the future.

\section{Review and Methodology}

According to the literature on the planning and design of congregate housing [23], it is shown that the development of the bathroom has been evolving since the 1940s, including the shift from a one-piece bathroom to a four-piece bathroom, the change from a bathroom without a piping closet to a bathroom with a piping closet and the management of the water space configuration. With more people paying attention to usage habits and quality of life nowadays, bathroom space has become an important space, despite the fact that it accounts for only a small portion of a house. The planning of bathroom space involves several crucial items; for instance, the drainage pipeline affects not only the residents but also the building itself. Through a literature review, it is shown that the drainage systems installed in the past were mostly based on the traditional piping system, with pipeline embedded in the wall. Moreover, the water space was not centrally managed, affecting the pipeline layout. Although a piping closet has been adopted in later designs, if a maintenance hole is not reserved, problems will still arise during pipeline maintenance in the future. When designing buildings in Japan, the durability of related materials is taken into account. As a result, the supporting body and the filling material are designed separately. In addition, the water space is centrally managed, and the water piping, as well as the power distribution closets, are moved closer to the public area. In recent years, the number of building construction projects in Taiwan adopting the same-floor drainage system has increased. With the appropriate concept of drainage design, hopefully, centralized management of pipelines can be considered during building planning, and suitable maintenance holes can be reserved for pipeline maintenance to ensure the normal function of the facility while extending its service life.

Same-Floor Drainage (SFD) is the conceptual principle for designing a building's drainage system and carrying out its construction. This principle can avoid potential ownership disputes in residential buildings. According to clear definitions and regulations, the piping system allocated in the private area will not cause conflicts for the maintenance and renovation of the piping system throughout its life cycle. Therefore, technologies and innovations, such as the skeleton and infill (SI) housing system, have been developed in recent decades, complying with the principle of same-floor drainage. The common construction method adopted in residential buildings is to lower the floor of the water supply and drainage area. Therefore, the maintenance and cleaning of the piping system will be restricted to a single residential unit only, and will not lead to disputes between the residents of two adjacent residential units connected vertically. 
In this study, net present value (NPV) was adopted to analyze the life cycle cost of bathroom systems [24]. The analysis is based on converting the initial cost and the maintenance or renovation costs during the 50-year operation period into net present values at a discount rate [24]. After the values were calculated, they were summed up to form the total life cycle cost. The life cycle cost analysis in this study set the space of the four bathrooms consistently to $150 \mathrm{~cm} \times 270 \mathrm{~cm} \times 340 \mathrm{~cm}$ [23]. The same types of bathroom fixtures were used and comparisons were made based on the manufacturer's price, cost price and installation fee. The subjects of analysis include the traditional piping system, descended floor piping system, raised floor piping system, and pre-wall piping system. A service life of 50 years was selected as the total life cycle for analysis [25]. The preliminary cost includes the initial construction cost of the four bathroom systems. The bathroom renovation and maintenance items for the four bathroom systems were grouped into two categories, namely the renewal of bathroom pipelines and the maintenance of facility pipelines. The cost of renovation or maintenance is the cost of partial renovation or maintenance for the bathrooms. The frequency of renovation or maintenance was set to once every $10,15,20,25,30,45$ and 50 years. The life cycle cost of a certain type of renovation or maintenance under each frequency was calculated and analyzed. In this study, the discount rates of $-0.01 \%$ and $0.29 \%$ were used to calculate the life cycle cost [26]. The discount rate values were determined based on the average interest rate of the five major banks in Taiwan, as defined by the Central Bank of the Republic of China, as well as the annual growth rate of the Consumer Price Index (CPI) for balancing inflation. The 20-year interest rate and inflation rate were also used as a reference. The final cluster was obtained through cluster analysis to improve the accuracy of future estimates. The formulas for NPV and LCC are as follows.

$$
\begin{gathered}
\mathrm{NPV}=\Sigma_{\mathrm{i}=1 \sim \mathrm{n}}(\mathrm{Ci}-\mathrm{Bi}) /(1+\mathrm{R})^{\mathrm{i}} \\
\mathrm{LCC}=\mathrm{I}_{\mathrm{O}}+\Sigma_{\mathrm{i}=1 \sim \mathrm{n}}(\mathrm{Ci}-\mathrm{Bi}) /(1+\mathrm{R})^{\mathrm{i}}
\end{gathered}
$$

NPV: net present value

LCC: Building life cycle cost

$\mathrm{I}_{\mathrm{o}}$ : Initial cost

$B_{\mathrm{i}}$ : Income for the i-year (this study is set at 0 )

$C_{i}$ : Refurbish or repair costs for the i-year

$\mathrm{N}$ : 50 years of service life in sanitary system

$\mathrm{R}$ : discounted rate, this study took $-0.01 \%$ and $0.29 \%$ and calculated the life cycle cost, respectively.

\section{Same-Floor Drainage Method for Buildings}

The drainage systems of residential buildings in Taiwan are all based on the traditional piping system, which connects the drainage pipeline of a condo from its floor to the ceiling of another condo downstairs. On the other hand, the same-floor drainage system refers to the installation of drainage system on the same floor, implying that drainage problem can be restricted to the same floor. The same-floor drainage system has the benefits of preventing potential ownership dispute, and avoiding damage to the main construction during leakage repair, reducing the generation of noise and excessive waste. The samefloor drainage system can be divided into three types, namely, the descended floor piping system, the raised floor piping system and the pre-wall piping system. Among them, the descended floor piping system and raised floor piping system can be further divided into backfill-type and non-backfill-type. Figure 1 shows the schematic definition diagram of residential property zoning. 

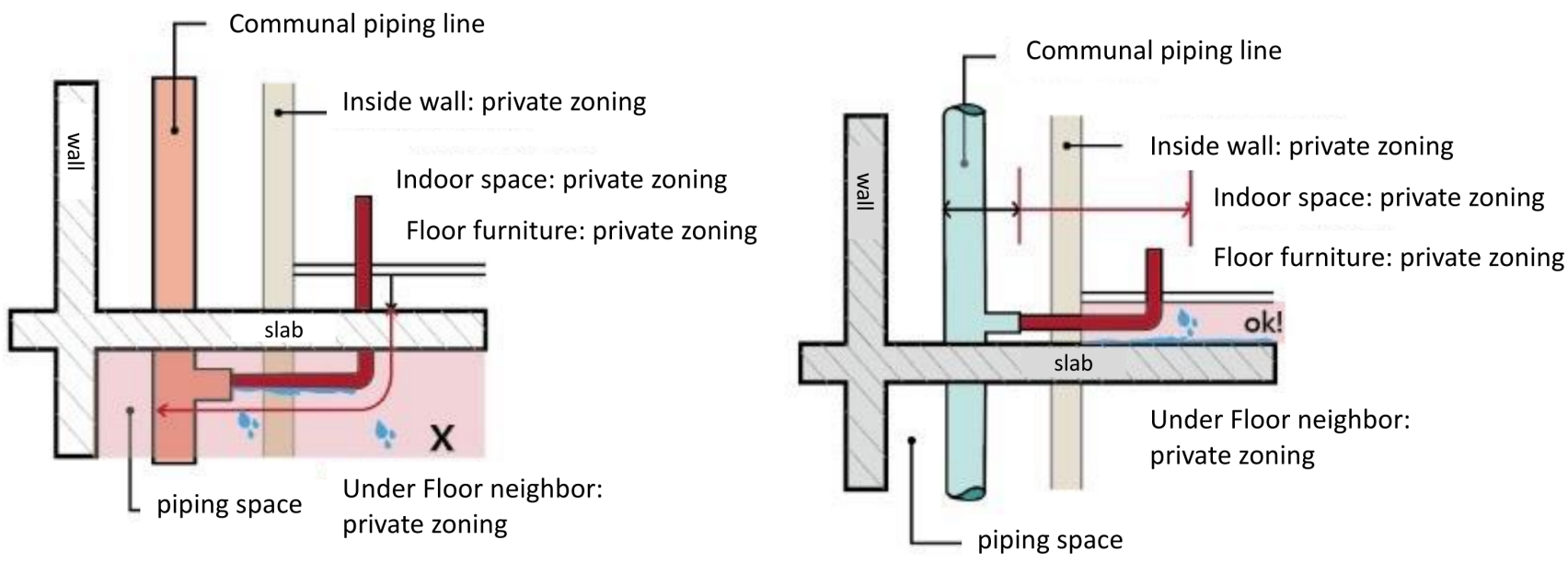

Figure 1. Schematic definition diagram of residential property zoning.

\subsection{Descended Floor Piping System}

Descended floor piping system refers to the use of the sunk space within the bathroom floor, which serves as space for pipeline installation as shows in Figure 2. The pipes used are based on their original sizes and no special pipes are required. In addition, each pipeline system is equipped with a main drain trap. In Taiwan, a descended floor piping system is mostly applied to bathrooms. The construction method includes the design with concrete backfill and the design without concrete backfill. For the one with concrete backfill, the loading of the concrete after backfilling shall be considered during the calculation of the building construction, For the design without backfill, galvanized steel supporting plate is used, serving as the second-layer support.

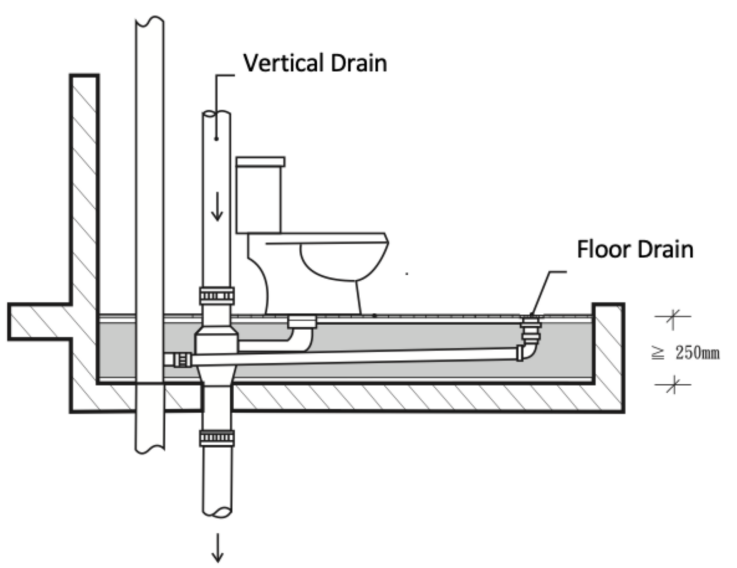

Figure 2. Schematic definition of the descended floor piping system.

\subsection{Raised Floor Piping System}

A raised floor piping system refers to the reservation of piping space on the surface of the same floor, as shown in Figure 3. One approach is to raise the hollow cement slab by more than $20 \mathrm{~cm}$, and the hollow cement slab surface material is placed on the cement brick as the second layer of pavement. Finally, it is finished with wall putty. The raised space is then used for pipeline installation. The second approach is to extend the original pipes to form exposed pipeline and then apply concrete backfill. The height of the floor will be raised by more than $15 \mathrm{~cm}$, resulting in a decrease in the net indoor height. This approach is mostly applied to the renovation of old houses. 


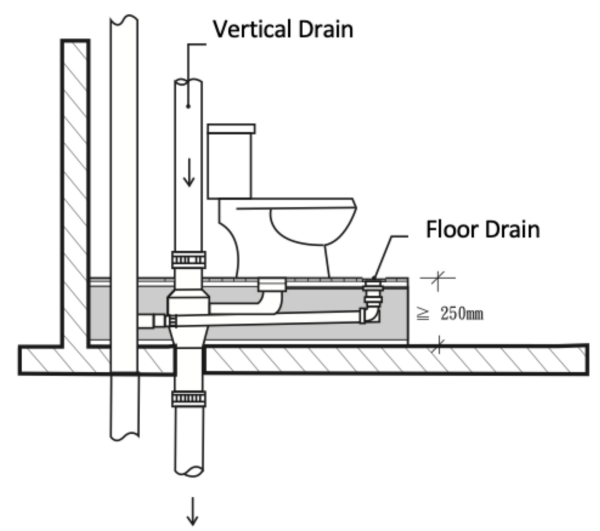

Figure 3. Schematic definition of the raised floor piping system.

\subsection{Pre-Wall Piping System}

A pre-wall piping system refers to the installation of pipeline in the bathroom space in front of the existing wall, with the pipeline enclosed in a light-weight material, forming a horizontal piping closet, as shown in Figure 4. Although the cost for this piping system is relatively high, the sound of flushing will be significantly reduced by the wall, giving rise to less noise. For those who wish to change the toilet's position in the future, such installation will not affect the configuration of the bathroom space, providing more flexibility in space planning. Since this piping method will increase the wall thickness by $15 \mathrm{~cm}$ or more, those adopting this installation for bathroom renovation should consider whether there is enough space for the construction. This installation is mostly used in public buildings, such as restaurants, gymnasiums, etc.

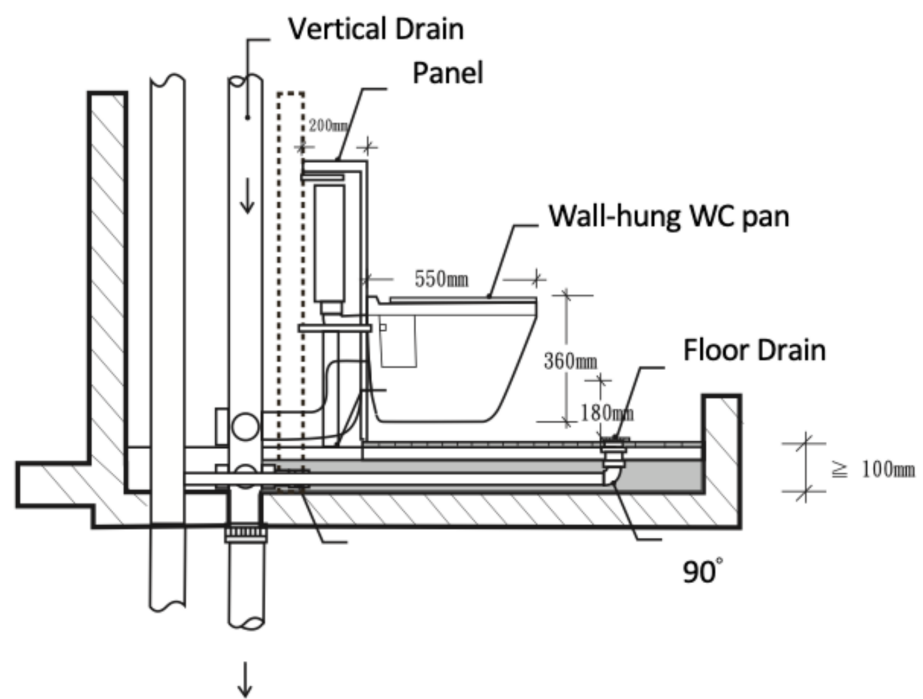

Figure 4. Schematic definition of the pre-wall piping system.

\section{Building Life Cycle Cost Analysis}

\subsection{Initial Constructionl Cost for Four Types of Bathroom Piping Systems}

Currently, the same-floor drainage technique is not common in Taiwan. Therefore, for cost analysis, market surveys of actual construction projects in northern, central and southern Taiwan, as well as in-depth interviews with industry experts from general contractors and construction companies, were conducted in this study. Based on the techniques, construction methods and materials used for the same-floor drainage, initial costs for building the sanitary system were obtained, thus improving the accuracy of the result. 
The initial cost of a bathroom system is mainly divided into two parts: the cost of the sanitary fixture and the total cost of the structure as well as the pipeline. For the cost of the sanitary fixture, same model of bathroom equipment was used. According to the results, among the four types of bathroom piping systems, the traditional piping system, the descended floor piping system and the raised floor piping system have the lowest cost of sanitary fixtures at NT\$30,600 $( \pm 0 \%)$, while the pre-wall piping system has the highest cost of sanitary fixtures at NT\$50,700 (+65\%). Since the pre-wall piping system requires the use of wall-mounted sanitary fixture, the price of the toilet and the bathroom sink is higher, resulting in higher costs.

In this study, the calculation of construction cost includes formwork, steel bars, concrete materials, water supply and drainage pipes, waterproofing work and tiles. Since the installation cost is already included in the price of each item, it was not added into the calculation. An additional second-layer paving cost was included for both the descended floor piping system without backfill and the raised floor piping system. As for the pre-wall piping system, the design included a fake wall, which is made of galvanized steel frame and painted panels. The initial costs of the four types of bathroom piping systems are shown in Table 1 . The cost of the traditional piping system is the lowest at NT\$165,000 $( \pm 0 \%)$, followed by the cost of the raised floor piping system with backfill at NT\$170,100 $(+3.1 \%)$, the cost of the raised floor piping system without backfill at NT $\$ 179,500(+8.8 \%)$, the cost of the descended floor piping system with backfill at NT\$183,600 $(+11.3 \%)$, the cost of the descended floor piping system without backfill at NT\$191,400 (+16.0\%) and the cost of the pre-wall piping system at NT\$213,600 (+29.5\%), showing that the pre-wall piping system has the highest initial cost.

Table 1. Construction initial cost for four types of bathroom piping systems.

\begin{tabular}{|c|c|c|c|c|c|c|}
\hline \multirow{2}{*}{ Project } & \multirow{2}{*}{$\begin{array}{l}\text { Traditional } \\
\text { Piping } \\
\text { System }\end{array}$} & \multicolumn{2}{|c|}{$\begin{array}{l}\text { Descended Floor } \\
\text { Piping System }\end{array}$} & \multicolumn{2}{|c|}{$\begin{array}{l}\text { Raised Floor Piping } \\
\text { System }\end{array}$} & \multirow{2}{*}{$\begin{array}{l}\text { Pre-Wall } \\
\text { Piping } \\
\text { System }\end{array}$} \\
\hline & & $\begin{array}{c}\text { With } \\
\text { Backfill }\end{array}$ & $\begin{array}{l}\text { Without } \\
\text { Backfill }\end{array}$ & $\begin{array}{l}\text { With } \\
\text { Backfill }\end{array}$ & $\begin{array}{l}\text { Without } \\
\text { Backfill }\end{array}$ & \\
\hline 1. Sanitary fixture cost & 30,600 & 30,600 & 30,600 & 30,600 & 30,600 & 50,700 \\
\hline 2. External wall construction (L-type) & 45,800 & 45,800 & 45,800 & 45,800 & 45,800 & 45,800 \\
\hline $\begin{array}{l}\text { 3. Construction of lightweight partition wall } \\
\text { with mortar-infill (including wall putty and } \\
\text { paint) (L-type) }\end{array}$ & 26,400 & 26,400 & 26,400 & 26,400 & 26,400 & 26,400 \\
\hline 4. Plasterwork & 4600 & 4600 & 4600 & 4600 & 4600 & 4600 \\
\hline 5. Waterproofing work & 9400 & 11,600 & 11,600 & 9400 & 9400 & 9400 \\
\hline 6. Wall tiling & 24,600 & 24,600 & 24,600 & 24,600 & 24,600 & 24,600 \\
\hline 7. Floor tiling & 7200 & 7200 & 7200 & 7200 & 7200 & 7200 \\
\hline 8. Ceiling work & 4900 & 4900 & 4900 & 4900 & 4900 & 4900 \\
\hline 9. Water supply and drain pipe work & 11,500 & 15,000 & 15,000 & 11,500 & 11,500 & 12,000 \\
\hline 10. Total drain trap & - & 6000 & 6000 & - & - & - \\
\hline $\begin{array}{l}\text { 11. Descended floor (Raised floor) backfilled } \\
\text { with lightweight concrete, foundation }\end{array}$ & - & 6900 & - & 5100 & - & - \\
\hline $\begin{array}{l}\text { 12. Pedestal, galvanized steel sheet } \\
\text { (including waterproof) }\end{array}$ & - & - & 14,700 & - & - & - \\
\hline 13. Gencore steel deck (including waterproof) & - & - & - & - & 14,500 & - \\
\hline 14. Galvanized steel frame piping wall & - & - & - & - & - & 28,000 \\
\hline Total & 165,000 & 183,600 & 191,400 & 170,100 & 179,500 & 213,600 \\
\hline Comparing with traditional bathroom & $( \pm 0 \%)$ & $(+11.3 \%)$ & $(+16.0 \%)$ & $(+3.1 \%)$ & $(+8.8 \%)$ & $(+29.5 \%)$ \\
\hline
\end{tabular}




\subsection{Estimation of the Renovation Costs for Bathroom Pipelines}

\subsubsection{Cost for Complete Replacement of Bathroom Pipeline}

The estimated costs for complete replacement of the pipelines in the four types of bathroom piping systems are shown in Table 2. The construction conditions are set as follows: the location of the sanitary system pipeline and the size of the bathroom space remains unchanged, while the original bathroom equipment, tiles, plaster layer, ceiling, waterproofing work and water supply/drainage pipelines are changed. The results show that the replacement cost of the traditional piping system is the highest at NT $\$ 147,300$ $( \pm 0 \%)$, followed by the replacement cost of the descended floor piping system without backfill at NT $\$ 143,300(-2.7 \%)$, the replacement cost of the raised floor piping system without backfill at NT\$140,900 $(-4.3 \%)$, the replacement cost of the descended floor piping system with backfill at NT\$135,400 (-8.1\%), the replacement cost of the raised floor piping system without backfill at NT $\$ 131,500(-10.7 \%)$ and the replacement cost of the pre-wall piping system at NT\$91,200 (-38.1\%).

Table 2. Costs for complete replacement of pipelines in the four types of bathroom piping systems.

\begin{tabular}{|c|c|c|c|c|c|c|}
\hline \multirow{2}{*}{ Project } & \multirow{2}{*}{$\begin{array}{l}\text { Traditional } \\
\text { Piping } \\
\text { System }\end{array}$} & \multicolumn{2}{|c|}{$\begin{array}{l}\text { Descended Floor } \\
\text { Piping System }\end{array}$} & \multicolumn{2}{|c|}{$\begin{array}{l}\text { Raised Floor Piping } \\
\text { System }\end{array}$} & \multirow{2}{*}{$\begin{array}{l}\text { Pre-Wall } \\
\text { Piping } \\
\text { System }\end{array}$} \\
\hline & & $\begin{array}{c}\text { With } \\
\text { Backfill }\end{array}$ & $\begin{array}{l}\text { Without } \\
\text { Backfill }\end{array}$ & $\begin{array}{c}\text { With } \\
\text { Backfill }\end{array}$ & $\begin{array}{l}\text { Without } \\
\text { Backfill }\end{array}$ & \\
\hline $\begin{array}{l}\text { 1. Floor, wall tiles including bottom mortar } \\
\text { removing, fixtures (including waste cleaning } \\
\text { and transportation) }\end{array}$ & 32,000 & 20,300 & 20,300 & 20,300 & 20,300 & 10,500 \\
\hline 2. Plasterwork & 9200 & 11,600 & 4800 & 9900 & 4800 & - \\
\hline 3. Waterproofing work & 9400 & 11,600 & 11,600 & 9400 & 9400 & - \\
\hline 4. Water supply and drain pipe work & 24,600 & 24,600 & 24,600 & 24,600 & 24,600 & - \\
\hline $\begin{array}{l}\text { 5. Pre-wall piping steel frame construction } \\
\text { (including pipeline replacement) }\end{array}$ & - & - & - & - & - & 30,000 \\
\hline 6. Wall tiling & 24,600 & 24,600 & 24,600 & 24,600 & 24,600 & - \\
\hline 7. Floor tiling & 7200 & 7200 & 7200 & 7200 & 7200 & - \\
\hline 8. Floor paving & - & - & 14,700 & - & 14,500 & - \\
\hline 9. Ceiling work & 9700 & 4900 & 4900 & 4900 & 4900 & \\
\hline 10. Sanitary fixture & 30,600 & 30,600 & 30,600 & 30,600 & 30,600 & 50,700 \\
\hline Total & 147,300 & 135,400 & 143,300 & 131,500 & 140,900 & 91,200 \\
\hline Comparing with traditional bathroom & $\pm 0 \%$ & $-8.1 \%$ & $-2.7 \%$ & $-10.7 \%$ & $-4.3 \%$ & $-38.1 \%$ \\
\hline
\end{tabular}

Note. Unit: New Taiwan Dollar (NTD).

The ranking of the above replacement costs is attributed to the fact that, since most of the partition walls in practice are lightweight partition walls, the labor and time required in the traditional wall removing job can be eliminated. As a result, when estimating the costs for the removal of floor and walls, plasterwork and painting, the values are slightly different. Another reason is because the differences in the construction method and materials selected for the descended floor piping system without backfill or the raised floor piping system may affect the estimation results. On the other hand, the pre-wall piping system is mainly based on the installation of a piping wall in front of the original wall. Such configuration allows pipelines of sanitary system to be replaced without affecting the original wall, saving significant amount of labor as well as material costs.

\subsubsection{Cost for Partial Replacement of Bathroom Pipeline}

The costs for partial replacement of pipelines in the four types of bathroom piping systems were estimated based on the scenario of toilet pipeline leakage, as shown in Table 3 . 
The construction items include removing bathroom fixtures and floor paving material, removing waste, breaking up concrete, replacing drainage pipeline, floor paving (including waterproofing) and installation of fixtures. The results show that the partial replacement cost of the traditional piping system, the descended floor piping system with backfill and the raised floor piping system with backfill is the highest at NT\$21,600 $( \pm 0 \%)$, followed by the cost of the descended floor piping system without backfill and the raised floor piping system without backfill at NT\$15,800 (-26.9\%), then the cost of the pre-wall piping system at NT $\$ 11,500(-46.8 \%)$. Since the descended floor piping system without backfill and the raised floor piping system without backfill have reserved maintenance holes, it is only required to remove the maintenance holes for partial replacement. Repair for the pre-wall piping system is mainly focused on the flush handle and the toilet tank. Since the maintenance hole is mostly located near the flush handle. Repair of the pre-wall piping system can be carried out simply by removing the cover of the flush handle. Although the initial construction cost of the pre-wall piping system is relatively high, the its maintenance cost is lower.

\subsection{Life Cycle Cost Analysis}

Figures 5-10 show the estimated life cycle costs for complete replacement as well as partial replacement of water supply and drain pipelines in the four types of bathroom piping systems.

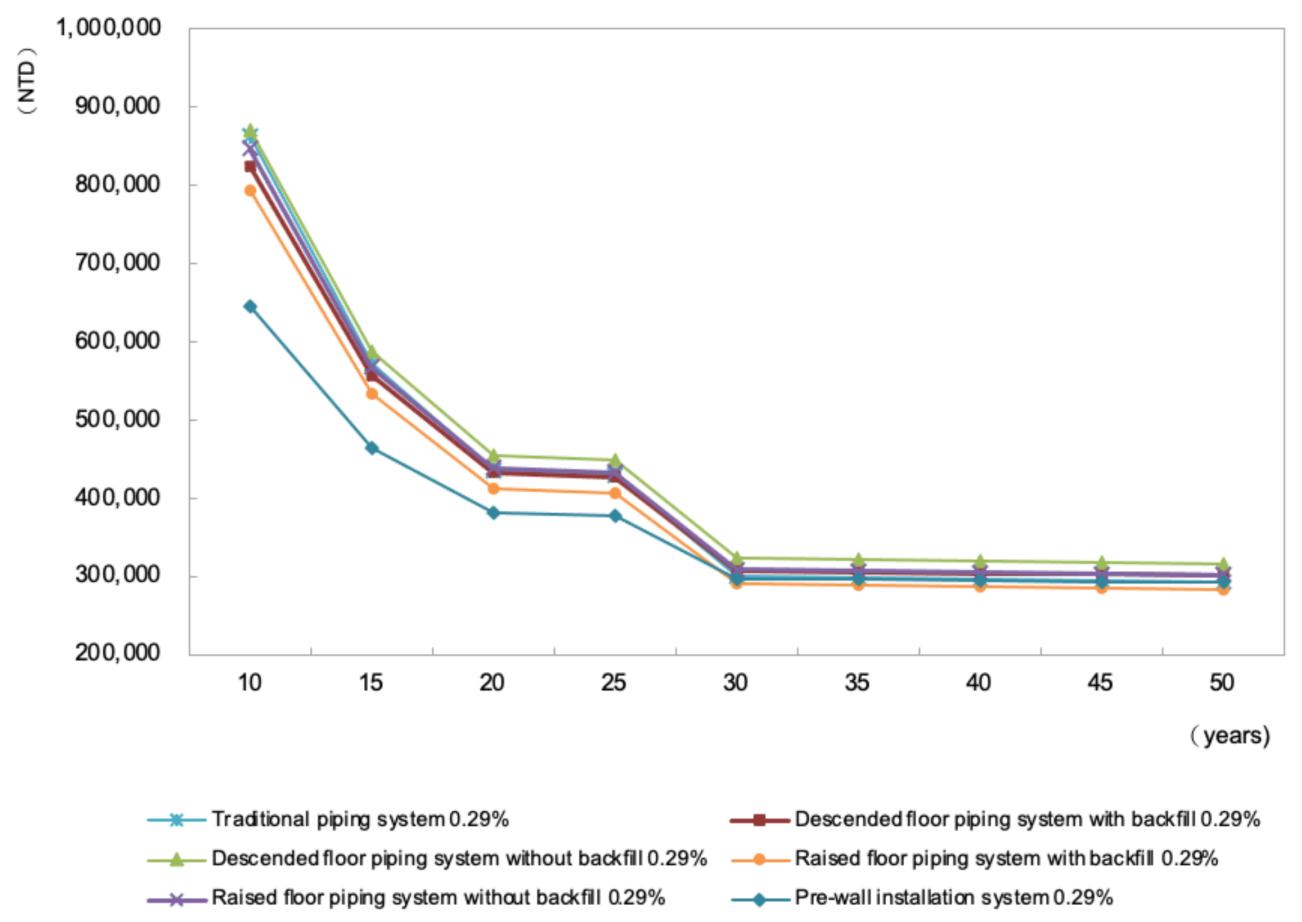

Figure 5. Life cycle costs for the complete replacement of pipelines in the four types of bathroom piping systems with discount rate of $0.29 \%$. 


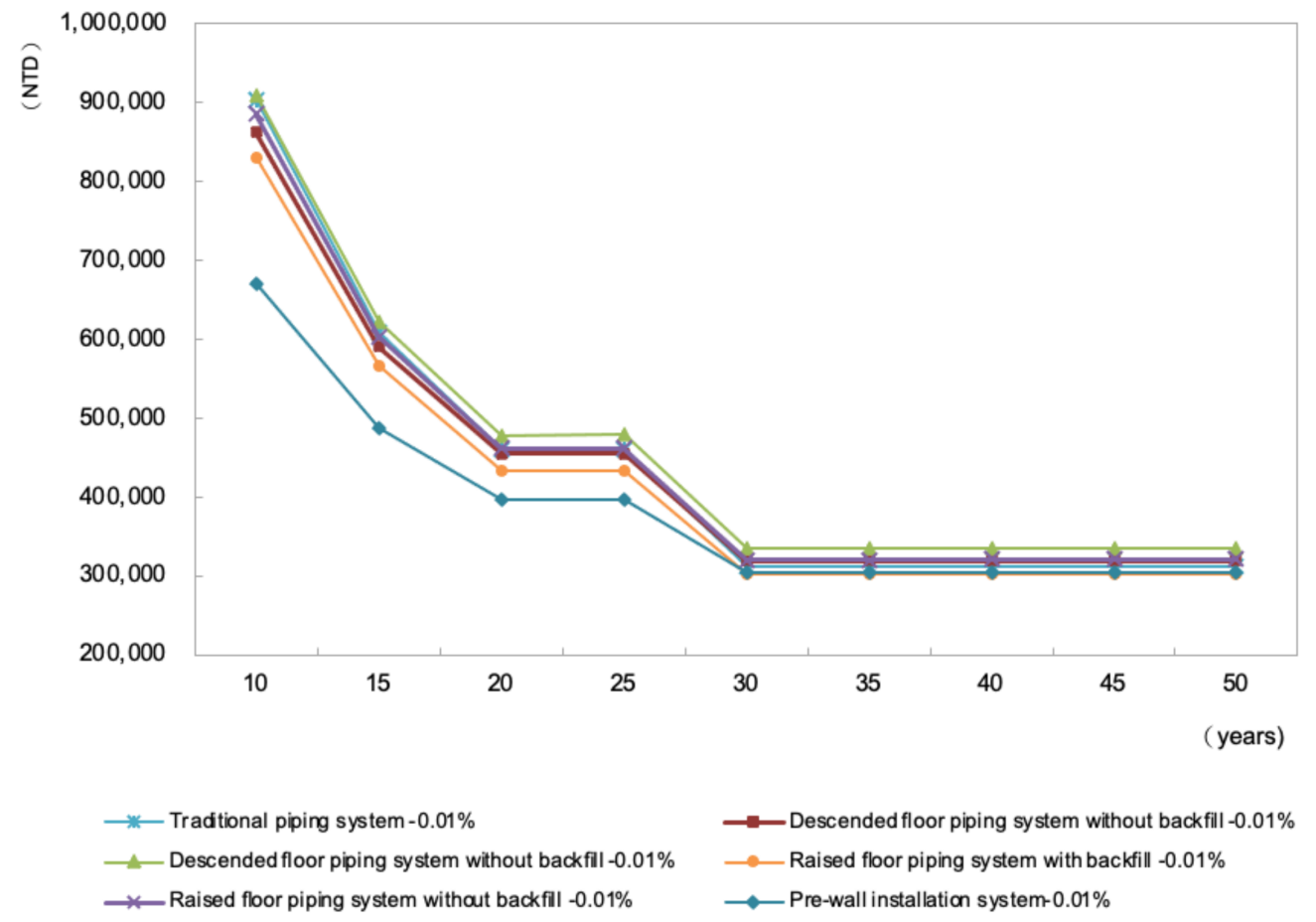

Figure 6. Life cycle costs for the complete replacement of pipelines in the four types of bathroom piping systems with discount rate of $-0.01 \%$.

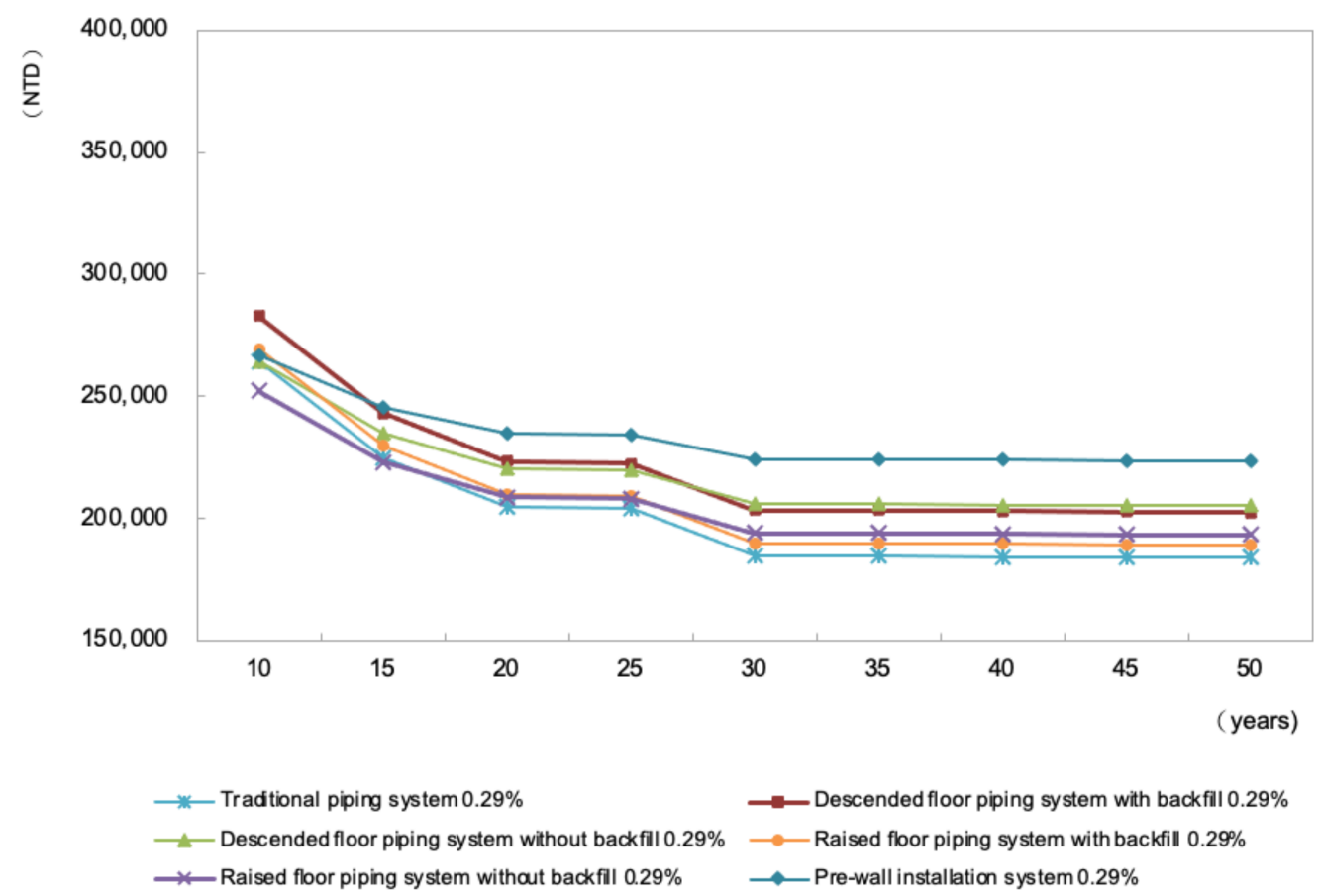

Figure 7. Life cycle costs for the partial replacement of pipelines in the four types of bathroom piping systems with discount rate of $0.29 \%$. 


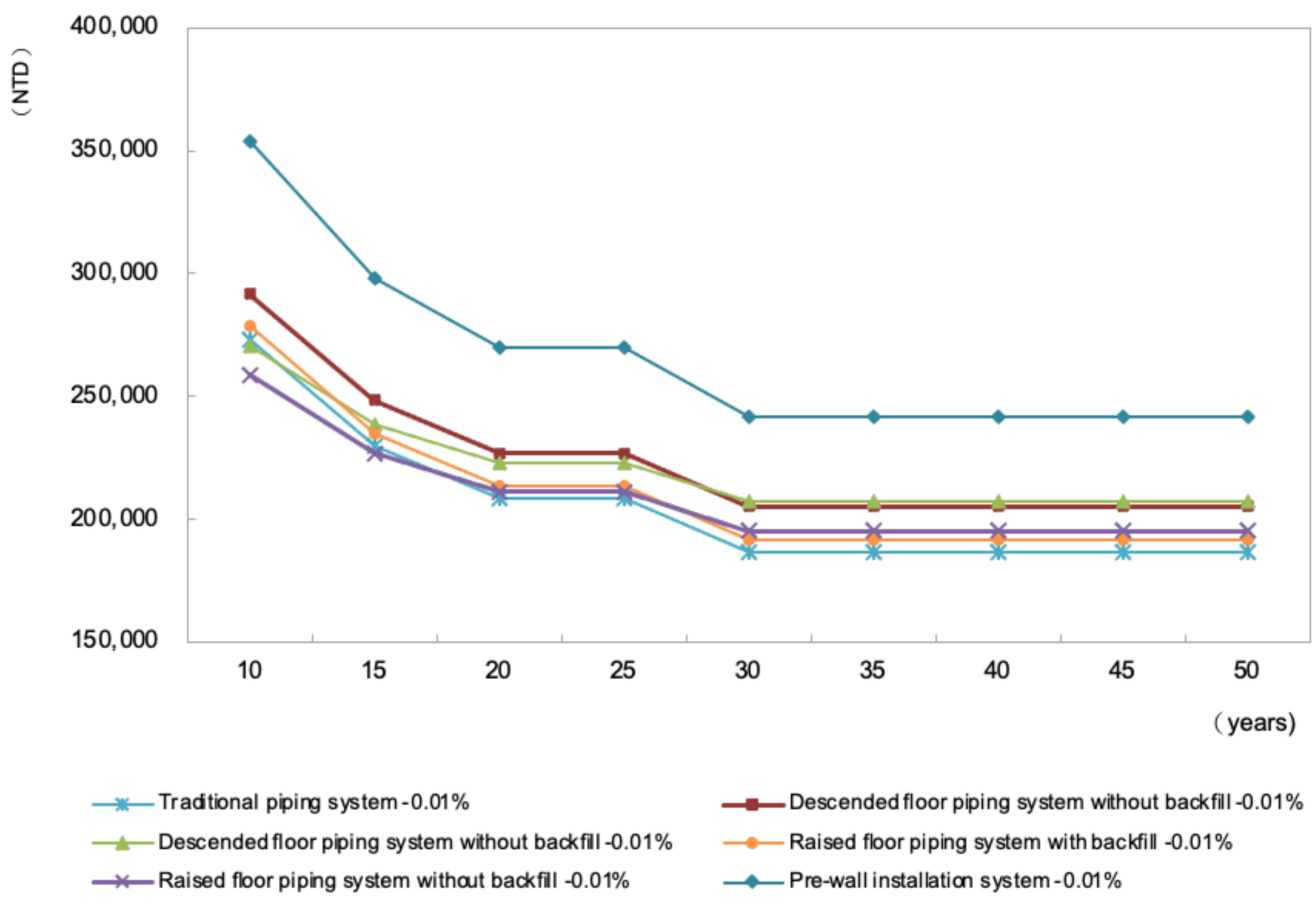

Figure 8. Life cycle costs for the partial replacement of pipelines in the four types of bathroom piping systems with discount rate of $-0.01 \%$.

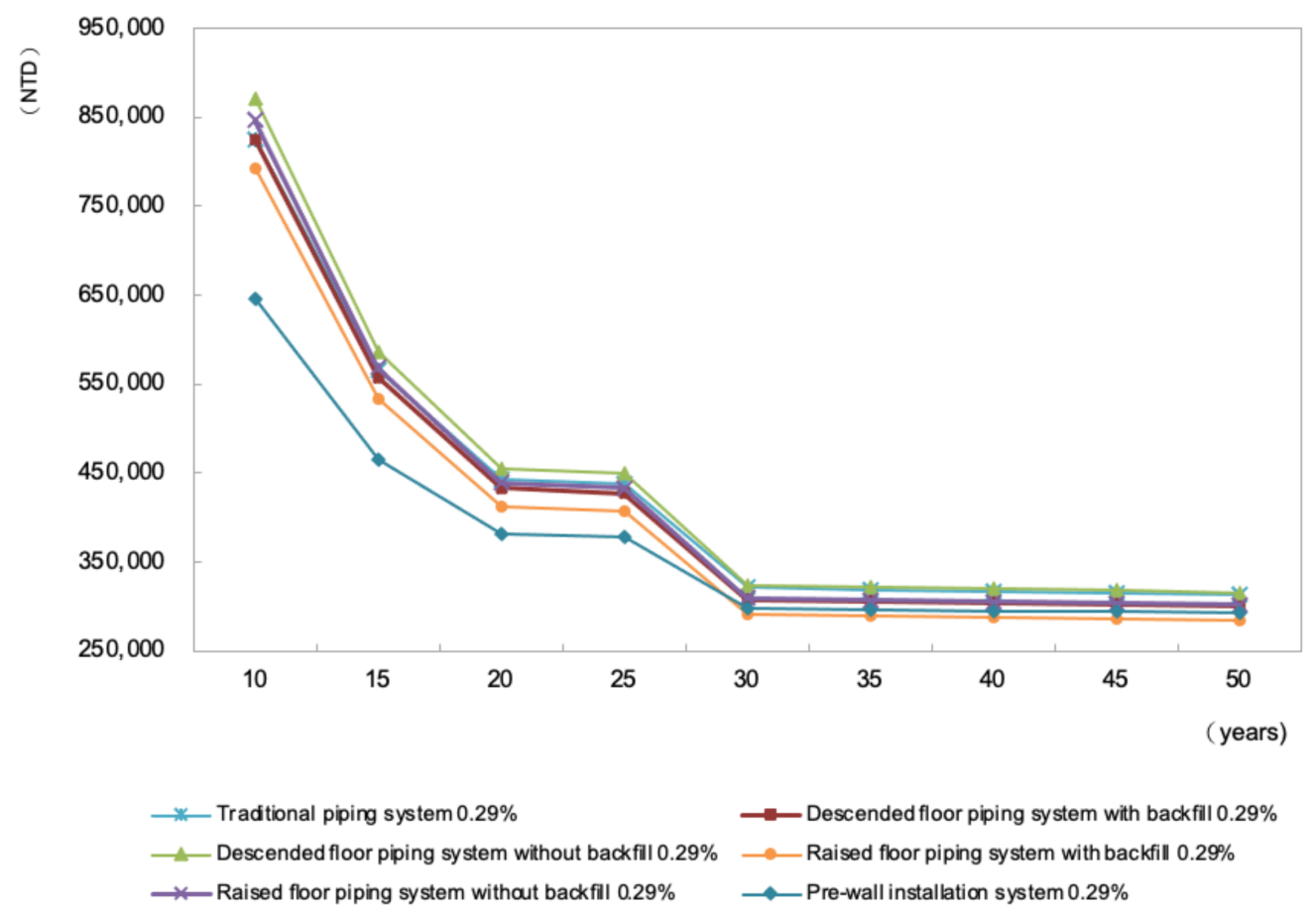

Figure 9. Life cycle costs for the complete replacement of pipelines in the four types of bathroom piping systems after changing the traditional piping system to the raised floor piping system with backfill, with discount rate of $0.29 \%$. 


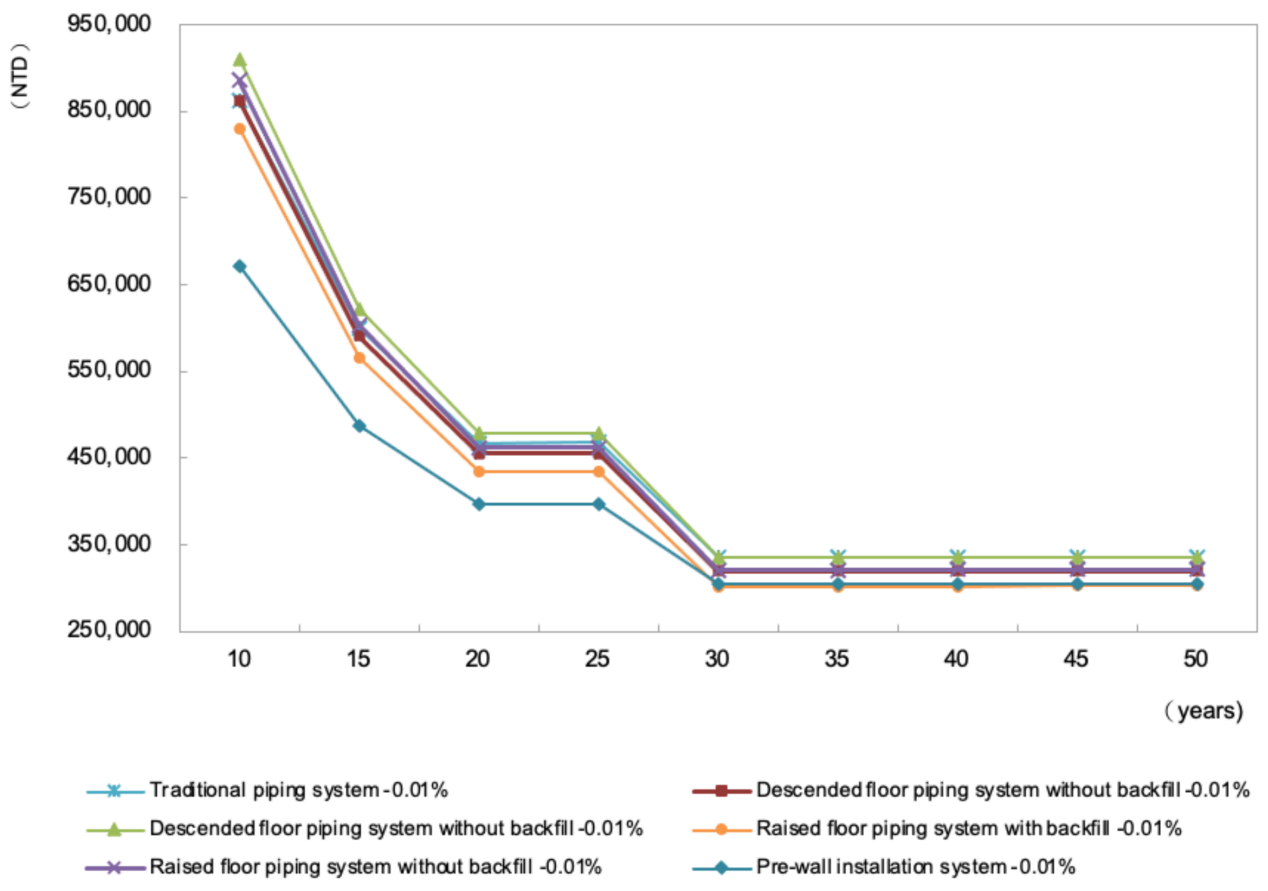

Figure 10. Life cycle costs for the complete replacement of pipelines in the four types of bathroom piping systems after changing the traditional piping system to the raised floor piping system with backfill, with discount rate of $-0.01 \%$.

Table 3. Costs for partial replacement of pipelines in the four types of bathroom piping systems.

\begin{tabular}{|c|c|c|c|c|c|c|}
\hline \multirow{2}{*}{ Project } & \multirow{2}{*}{$\begin{array}{c}\text { Traditional } \\
\text { Piping } \\
\text { System }\end{array}$} & \multicolumn{2}{|c|}{$\begin{array}{l}\text { Descended Floor Piping } \\
\text { System }\end{array}$} & \multicolumn{2}{|c|}{$\begin{array}{c}\text { Raised Floor Piping } \\
\text { System }\end{array}$} & \multirow{2}{*}{$\begin{array}{c}\text { Pre-Wall } \\
\text { Piping } \\
\text { System }\end{array}$} \\
\hline & & $\begin{array}{c}\text { With } \\
\text { Backfill }\end{array}$ & $\begin{array}{l}\text { Without } \\
\text { Backfill }\end{array}$ & $\begin{array}{c}\text { With } \\
\text { Backfill }\end{array}$ & $\begin{array}{l}\text { Without } \\
\text { Backfill }\end{array}$ & \\
\hline $\begin{array}{l}\text { 1. Dismantling of fixtures, floor } \\
\text { paving material }\end{array}$ & 3500 & 3500 & 2000 & 3500 & 2000 & - \\
\hline 2. Waste removal fee & 3500 & 3500 & 3500 & 3500 & 3500 & 3500 \\
\hline 3. Water supply and drain pipe work & 4500 & 4500 & 4500 & 4500 & 4500 & 4500 \\
\hline 4. Waterproofing work & 2000 & 2000 & - & 2000 & - & - \\
\hline 5. Floor paving & 4600 & 4600 & 2300 & 4600 & 2300 & - \\
\hline 6. Toilet installation & 3500 & 3500 & 3500 & 3500 & 3500 & 3500 \\
\hline Total & 21,600 & 21,600 & 15,800 & 21,600 & 15,800 & 11,500 \\
\hline Comparing with traditional bathroom & $\pm 0 \%$ & $\pm 0 \%$ & $-26.9 \%$ & $\pm 0 \%$ & $-26.9 \%$ & $-46.8 \%$ \\
\hline
\end{tabular}

Note. New Taiwan Dollar (NTD).

1. Life cycle costs for the complete replacement of pipelines in the four types of bathroom piping systems

As shown in Figure 5, with the discount rate of $0.29 \%$ and the renovation frequency of once every 15 years, the lifecycle cost of the descended floor piping system without backfill is the highest, followed by the life cycle cost of the traditional piping system, the life cycle cost of the raised floor piping system without backfill, the life cycle cost of the descended floor piping system with backfill, the life cycle cost of the raised floor piping system with backfill and the life cycle cost of the pre-wall piping system. If the renovation frequency is changed to once every 20 years, the life cycle costs of the traditional piping system and the 
raised floor piping system with backfill will be different from the corresponding life cycle costs with renovation frequency of once every 15 years. As shown in Figure 6, with the discount rate of $-0.01 \%$, the life cycle costs for complete replacement of pipelines in the four types of bathroom piping systems are higher than those with discount rate of $0.29 \%$. However, the ranking in terms of the life cycle costs for the four types of bathroom piping systems is independent of the discount rate.

2. Life cycle costs for the partial replacement of pipelines in the four types of bathroom piping systems

Life cycle costs for the partial replacement of pipelines in the four types of bathroom piping system, with the discount rate of $0.29 \%$ and the renovation frequency of once every 15 years, are shown in Figure 7. It is noted that the lifecycle cost of the pre-wall piping system is the highest, followed by the life cycle cost of the descended floor piping system with backfill, the life cycle cost of the descended floor piping system without backfill, the life cycle cost of the raised floor piping system with backfill, the life cycle cost of the traditional piping system and the life cycle cost of the raised floor piping system without backfill. For the renovation frequency of once every 20 years, the life cycle costs of the traditional piping system and the raised floor piping system without backfill are different from the corresponding life cycle costs with renovation frequency of once every 15 years. As shown in Figure 8, with the discount rate of $-0.01 \%$, the life cycle costs for partial replacement of pipelines in the four types of bathroom piping systems are higher than those with a discount rate of $0.29 \%$. However, the ranking in terms of the lifecycle costs for the four types of bathroom piping systems is independent of the discount rate.

3. Life cycle costs for the complete replacement of pipelines in the four types of bathroom piping systems after changing the traditional piping system to the raised floor piping system with backfill

Due to the hoisting constraints of the pipeline in the bathroom space, most of the current practices for sanitary pipeline renewal will adopt exposed pipeline. However, since the pipeline is based on the traditional piping system, it must be changed to the raised floor piping system when carrying out pipeline renewal. This study aims to estimate the life cycle costs for the complete replacement of the water supply and drain pipelines in the four types of bathroom piping system after changing the traditional piping system to the raised floor piping system.

The results in Figure 9 show that with the discount rate of $0.29 \%$ and the renovation frequency of once every 10 years, if the complete replacement is carried out from the traditional piping system, it will cost nearly NT $\$ 35,000$ more than carrying out the complete replacement after it has been changed to the raised floor piping system with backfill. Moreover, if the renovation frequency is changed to once every 15 years, the life cycle cost for carrying out complete replacement from the traditional piping system will be nearly NT\$7000 more than carrying out the complete replacement after it has been changed to the raised floor piping system with backfill. The results suggest that the continuous use of the traditional piping system not only will result in higher costs when carrying out the complete replacement of the pipeline, but also create the need for negotiating with the neighbor downstairs, making the replacement process tedious. However, if the pipeline is changed to the same-floor drainage system, it not only will save a lot of money for future replacement, but also avoids the need for negotiating with the neighbors downstairs, benefiting the construction process of future replacement, as well. When the discount rate of the four types of bathroom piping systems is at $-0.01 \%$, as shown in Figure 10, the ranking in terms of the life cycle cost remains unchanged.

\subsection{Discussion}

From the results of the initial costs for the four types of bathroom piping systems mentioned above in Section 4.1, it is shown that the traditional piping systems have advantages in both initial construction costs and life cycle costs, which meet the expectations of 
the users, designers and constructors, making the traditional piping system still the most commonly used bathroom piping system.

Although the initial construction cost of the descended floor piping system and the raised floor piping system is higher than that of the traditional piping system by $3.1-16.0 \%$, they can reduce the future bathroom pipeline replacement and maintenance cost by up to $27 \%$, suggesting that the descended floor piping system and the raised floor piping system still have their cost advantages and have the potential to compete with the traditional piping system. On the other hand, although the initial construction cost of the pre-wall piping system is about $30 \%$ higher than that of the traditional piping system, it can reduce the future pipeline maintenance cost by up to $47 \%$ compared with the traditional piping system. Furthermore, it showed the best performance in terms of maintenance time and sanitary fixture configuration flexibility.

After determining the costs for the same-floor drainage system, the actual congregate housing in Taipei was selected as the research subject in this study. The total construction cost of the congregate housing is about NT $\$ 371$ million, including falsework, foundation construction, basement safety support, earth excavation and filling, layout, renovation and door and window installation. Among them, the construction projects accounted for $86 \%$ of the total cost, while the water supply and drainage, as well as sanitary facility installation projects, accounted for about $3 \%$ of the total cost.

From the cost analysis of this real case study, it is found that the total bathroom area of Building A and Building B of the congregate housing is approximately 255 pings $\left(842.3330 \mathrm{~m}^{2}\right)$, with the space of each bathroom set to $150 \mathrm{~cm} \times 270 \mathrm{~cm} \times 340 \mathrm{~cm}$. Based on the estimated costs mentioned previously, the costs per unit area of the four types of bathroom piping systems are determined as follows: NT\$134,146/ping for the traditional piping, NT\$149,268/ping for the descended floor piping system with backfill, NT\$155,610/ping for the descended floor piping system without backfill, NT\$138,293/ping for the raised floor piping system with backfill, NT\$145,935/ping for the raised floor piping system without backfill and NT $\$ 173,659 /$ ping for the pre-wall piping system. Based on the cost per unit area for the four types of bathroom piping systems calculated above, the percentage of the construction cost for various piping systems to the total cost is determined as follows: the traditional piping system accounts for $9.2 \%( \pm 0 \%)$ of the total cost, the descended floor piping system with backfill accounts for $10.3 \%(+1.0 \%)$ of the total cost, the descended floor piping system without backfill accounts for $10.7 \%(+1.5 \%)$ of the total cost, the raised floor piping system with backfill accounts for $9.5 \%(+0.3 \%)$ of the total cost, the raised floor piping system without backfill accounts for $10.0 \%(+0.8 \%)$ of the total cost and the pre-wall piping system accounts for $11.9 \%(+2.7 \%)$ of the total cost. A cost-benefit analysis of the four types of bathroom piping system is shown in Table 4 . Since the construction and pipelines costs are included in the calculation of the cost per unit area, the percentage of the construction cost for various piping systems to the total cost will be higher than that for the original drainage and sanitary equipment project.

Table 4. Cost-benefit analysis of the four types of bathroom piping systems.

\begin{tabular}{|c|c|c|c|c|c|c|c|}
\hline \multirow{2}{*}{ Cost-Benefit Analysis } & \multirow{2}{*}{$\begin{array}{l}\text { Bathroom Piping } \\
\text { System }\end{array}$} & \multirow{2}{*}{$\begin{array}{c}\text { Traditional } \\
\text { Piping } \\
\text { System }\end{array}$} & \multicolumn{2}{|c|}{$\begin{array}{l}\text { Descended Floor } \\
\text { Piping System }\end{array}$} & \multicolumn{2}{|c|}{$\begin{array}{l}\text { Raised Floor Piping } \\
\text { System }\end{array}$} & \multirow{2}{*}{$\begin{array}{c}\text { Pre-Wall } \\
\text { Piping } \\
\text { System }\end{array}$} \\
\hline & & & $\begin{array}{c}\text { With } \\
\text { Backfill }\end{array}$ & $\begin{array}{l}\text { Without } \\
\text { Backfill }\end{array}$ & $\begin{array}{c}\text { With } \\
\text { Backfill }\end{array}$ & $\begin{array}{l}\text { Without } \\
\text { Backfill }\end{array}$ & \\
\hline \multicolumn{8}{|c|}{ Cost analysis } \\
\hline \multicolumn{2}{|c|}{$\begin{array}{l}\text { Initial construction cost for various bathroom } \\
\text { piping systems }\end{array}$} & $\begin{array}{l}165,000 \\
( \pm 0 \%)\end{array}$ & $\begin{array}{c}183,600 \\
(+11.3 \%) \\
\end{array}$ & $\begin{array}{c}191,400 \\
(+16.0 \%)\end{array}$ & $\begin{array}{l}170,100 \\
(+3.1 \%) \\
\end{array}$ & $\begin{array}{l}179,500 \\
(+8.8 \%) \\
\end{array}$ & $\begin{array}{c}213,600 \\
(+29.5 \%) \\
\end{array}$ \\
\hline \multicolumn{2}{|c|}{$\begin{array}{l}\text { Cost for complete replacement of pipelines in } \\
\text { various bathroom piping systems }\end{array}$} & $\begin{array}{l}147,300 \\
( \pm 0 \%)\end{array}$ & $\begin{array}{l}135,400 \\
(-8.1 \%)\end{array}$ & $\begin{array}{l}143,300 \\
(-2.7 \%)\end{array}$ & $\begin{array}{l}131,500 \\
(-10.7 \%)\end{array}$ & $\begin{array}{l}140,900 \\
(-4.3 \%)\end{array}$ & $\begin{array}{c}91,200 \\
(-38.1 \%)\end{array}$ \\
\hline
\end{tabular}


Table 4. Cont.

\begin{tabular}{|c|c|c|c|c|c|c|}
\hline \multirow{2}{*}{ Cost-Benefit Analysis } & \multirow{2}{*}{$\begin{array}{l}\text { Traditional } \\
\text { Piping } \\
\text { System }\end{array}$} & \multicolumn{2}{|c|}{$\begin{array}{l}\text { Descended Floor } \\
\text { Piping System }\end{array}$} & \multicolumn{2}{|c|}{$\begin{array}{l}\text { Raised Floor Piping } \\
\text { System }\end{array}$} & \multirow{2}{*}{$\begin{array}{l}\text { Pre-Wall } \\
\text { Piping } \\
\text { System }\end{array}$} \\
\hline & & $\begin{array}{c}\text { With } \\
\text { Backfill }\end{array}$ & $\begin{array}{l}\text { Without } \\
\text { Backfill }\end{array}$ & $\begin{array}{c}\text { With } \\
\text { Backfill }\end{array}$ & $\begin{array}{l}\text { Without } \\
\text { Backfill }\end{array}$ & \\
\hline $\begin{array}{l}\text { Cost for partial replacement of pipelines in } \\
\text { various bathroom piping systems }\end{array}$ & $\begin{array}{l}21,600 \\
( \pm 0 \%)\end{array}$ & $\begin{array}{l}21,600 \\
( \pm 0 \%)\end{array}$ & $\begin{array}{c}15,800 \\
(-26.9 \%)\end{array}$ & $\begin{array}{l}21,600 \\
( \pm 0 \%)\end{array}$ & $\begin{array}{c}15,800 \\
(-26.9 \%)\end{array}$ & $\begin{array}{c}11,500 \\
(-46.8 \%)\end{array}$ \\
\hline $\begin{array}{l}\text { Life cycle cost for complete replacement of } \\
\text { pipelines in various bathroom piping systems } \\
\text { with renovation frequency of once every } 15 \\
\text { years and discount rate of } 0.29 \%\end{array}$ & $\begin{array}{l}571,761 \\
( \pm 0 \%)\end{array}$ & $\begin{array}{l}557,316 \\
(-2.5 \%)\end{array}$ & $\begin{array}{l}586,921 \\
(+2.7 \%)\end{array}$ & $\begin{array}{l}533,052 \\
(-6.8 \%)\end{array}$ & $\begin{array}{l}567397 \\
(-0.6 \%)\end{array}$ & $\begin{array}{c}468,320 \\
(-18.1 \%)\end{array}$ \\
\hline $\begin{array}{l}\text { life cycle cost for partial replacement of } \\
\text { pipelines in various bathroom piping systems } \\
\text { with renovation frequency of once every } 15 \\
\text { years and discount rate of } 0.29 \%\end{array}$ & $\begin{array}{l}224,818 \\
( \pm 0 \%)\end{array}$ & $\begin{array}{l}243,218 \\
(+8.2 \%)\end{array}$ & $\begin{array}{l}235,009 \\
(+4.5 \%)\end{array}$ & $\begin{array}{l}229,718 \\
(+2.2 \%)\end{array}$ & $\begin{array}{l}223,109 \\
(-0.8 \%)\end{array}$ & $\begin{array}{c}248,341 \\
(+10.5 \%)\end{array}$ \\
\hline $\begin{array}{l}\text { Percentage of construction cost for the } 4 \text { types } \\
\text { of bathroom piping systems to total cost } \\
\text { calculated based on empirical case study }\end{array}$ & $\begin{array}{c}9.2 \% \\
( \pm 0 \%)\end{array}$ & $\begin{array}{c}10.3 \% \\
(+1.0 \%)\end{array}$ & $\begin{array}{c}10.7 \% \\
(+1.5 \%)\end{array}$ & $\begin{array}{c}9.5 \% \\
(+0.3 \%)\end{array}$ & $\begin{array}{c}10.0 \% \\
(+0.8 \%)\end{array}$ & $\begin{array}{c}11.9 \% \\
(+2.7 \%)\end{array}$ \\
\hline \multicolumn{7}{|c|}{ Benefit Analysis } \\
\hline Maintenance performance (Time) & $2-3$ days & $2-3$ days & 1-2 days & $2-3$ days & 1-2 days & $0.5-1$ days \\
\hline Time required for pipeline replacement & 14-20 days & $\begin{array}{c}14-20 \\
\text { days }\end{array}$ & $6-8$ days & $\begin{array}{l}\text { 14-20 } \\
\text { days }\end{array}$ & 4-6 days & $6-8$ days \\
\hline Pipeline space & small & large & large & medium & large & medium \\
\hline Inspection and repair performance & difficult & difficult & acceptable & difficult & acceptable & easy \\
\hline Precision requirement for on-site construction & low & medium & high & low & high & medium \\
\hline
\end{tabular}

Note. Unit: New Taiwan Dollar (NTD).

\section{Conclusions}

The appropriateness of the design of the drainage system of a building has a great impact on its life cycle. From the perspective of the life cycle cost of the building, if the goal is to extend the operation, as well as the management period, of the building and to reduce the maintenance costs in the future, a correct drainage method should be implemented in the early stages of building planning to avoid potential ownership conflicts raised during the repair of water leakage over time.

The traditional bathroom system, which is based on wet construction, was the most commonly seen construction and piping method in the early days of Taiwan. In this system, the pipelines for water supply and drainage are primarily buried in walls or structural walls, or penetrated through the floor to enter a vertical pipeline space. Such a pipeline configuration will cause great difficulties and troubles for future maintenance and repair of the pipeline. Since the standardized building piping space and drainage facility conditions currently available are unable to meet the requirements of modern drainage design, and with the substantial number of water appliances in the bathroom space, the traditional floorpenetrating piping design may lead to chaos in piping and cause difficulties in subsequent maintenance and cleaning. In addition, old buildings often have issues, such as frequent water leakage and difficulty in facility renewal and renovation, as well house ownership and noise problems. In recent years, Taiwan has taken the initiative in developing new construction equipment and technologies, hoping that the same-floor drainage system can be adopted to gradually replace the traditional drainage system.

Pipelines of the same-floor drainage in buildings are installed on the same floor, and most of them are equipped with the new type of drain trap. According to the investigation and analysis of the actual cases conducted in this study and in terms of overall construction costs, although the use of the same-floor drainage increases the cost by about $0.3-2.7 \%$, 
it benefits the maintenance and replacement of the pipelines during their life cycle. For regular maintenance, only cleaning of the drain trap is required. For repair or replacement of the piping system, since maintenance holes are reserved for the same-floor drainage with the descended/raised floor piping system without backfill, it is only necessary to remove the reserved maintenance holes when carrying out repairs. Such convenience also applies to same-floor drainage with pre-wall piping system; it is only necessary to remove the light-weight partition wall when carrying out repairs. Therefore, same-floor drainage outperforms the traditional piping system in terms of maintenance and construction time. Consequently, from the perspective of property management, the introduction of the samefloor drainage system in the preliminary design stage can not only extend the service life of the building and reduce maintenance costs in the future, but also improve the safety and comfort of the building.

Author Contributions: Conceived and designed the research concept, W.-J.L. and C.-L.C.; methodology, C.-L.C.; performed the investigation and analyzed the data, W.-J.L. and C.-J.L.; writing-original draft preparation, W.-J.L.; writing-review and editing, W.-J.L. All authors have read and agreed to the published version of the manuscript.

Funding: This research received no external funding.

Institutional Review Board Statement: Not applicable.

Informed Consent Statement: Not applicable.

Conflicts of Interest: The authors declare no conflict of interest.

\section{References}

1. Jack, L.B.; Cheng, C.L.; Lu, W.H. Numerical simulation of pressure and airflow response of building drainage ventilation system. Build. Serv. Eng. Res. Technol. 2006, 27, 141-152. [CrossRef]

2. Liao, W.J.; Mui, K.W.; Cheng, C.L.; Wong, L.T.; He, K.C. Air pressure fluctuations of drainage stacks at a high-rise office building. Indoor Built Environ. 2011, 20, 412-419. [CrossRef]

3. Cheng, C.L.; Liao, W.J.; Lo, C.S.; Peng, J., Jr. A tool for detecting and diagnosing faults in the drainage systems of existing buildings. Indoor Built Environ. 2017, 26, 108-118. [CrossRef]

4. Ching, C.-L.; Chiang, N.-J. Study on Lifetime of Water Supply Plumbing in Taiwan Apartment Houses -Case Study of Six Examples in Taipei. J. Archit. 2001, 36, 127-139.

5. Cheng, C.L.; Yen, C.J.; Wong, L.T.; Ho, K.C. An Evaluation Tool of Infection Risk Analysis for Drainage Systems in High-rise Residential Buildings. Build. Serv. Eng. Res. Technol. 2008, 29, 233-248. [CrossRef]

6. Cheng, C.L.; Liao, W.J.; He, K.C.; Yen, C.J. A Non-Destructive Testing Method and Analysis for Air Pressure Distribution in the Stacks of Building Drainage Systems. In Proceedings of the ASME Pressure Vessels and Piping Division Conference, Chicago, IL, USA, 27-31 July 2008.

7. Cheng, C.L.; Mui, K.W.; Wong, L.T.; Yen, C.J.; He, K.C. Characteristics of air pressure fluctuations in high-rise drainage stacks. Build. Environ. 2010, 45, 84-90. [CrossRef]

8. World Health Organization (WHO). Inadequate Plumbing Systems Likely Contributed to SARS Transmission; WHO/780; WHO Press Release: Geneva, Switzerland, 2003; pp. 1-2.

9. Hung, H.C.K.; Chan, D.W.T.; Law, L.K.C.; Chan, E.H.W.; Wong, E.S.W. Industrial experience and research into the causes of SARS virus transmission in a high-rise residential housing estate in Hong Kong. Build. Serv. Eng. Res. Technol. 2006, 27, 91-102. [CrossRef]

10. Gormley, M.; Templeton, K.; Kelly, D.A.; Hardie, A. Environmental conditions and the prevalence of norovirus in hospital building drainage system wastewater and airflows. Build. Serv. Eng. Res. Technol. 2013, 35, 244-253. [CrossRef]

11. Benitez, M.A. Expert committee reviews SARS outbreak in Hong Kong. Lancet 2003, 362, 624. [CrossRef]

12. Li, Y.; Duan, S.; Yu, I.T.S.; Wong, L.T. Multi-zone modeling of probable SARS virus transmission by airflow between flats in Block, E.; Amoy Gardens. Indoor Air 2005, 15, 96-111. [CrossRef] [PubMed]

13. Gormley, M.; Kelly, D.A. Pathogen loading and environmental conditions found in hospital building drainage system wastewater and airflows. In Proceedings of the CIBW62, 37th International Symposium for Water Supply and Drainage for Buildings, Aveiro, Portugal, 25-28 September 2011; pp. 287-292.

14. Chung, S.C.; Cheng, C.L.; Liao, W.J.; Chen, H.J. Study on new style seal trap and application in building drainage system. In Proceedings of the CIB-W62 38th International Symposium, Edinburgh, UK, 28-30 August 2012; pp. 157-168.

15. Lu, W.-H.; Cheng, C.-L.; Tu, K.-J.; Chou, Y.-C. Investigation and Development Analysis of Building Drainage System for Apartment Houses. J. Archit. 2003, 43, 69-85. 
16. Cheng, C.L.; Chen, C.J.; Liao, W.J. Performance evaluation for same-floor drain technology in residential buildings. In Proceedings of the 43th International Symposium of CIB W064 on Water Supply and Drainage for Buildings, Haarlem, The Netherlands, 23-25 August 2017.

17. Cheng, C.L.; Chen, C.J.; Liao, W.J. Consideration of same-floor drain as life-cycle maintenance solution in residential buildings. In Proceedings of the 44th International Symposium of CIB W064 on Water Supply and Drainage for Buildings, Azores, Portugal, 28-30 August 2018.

18. Cheng, C.-L.; Lee, M.-C. Research on Hot Water Issues in Residential Buildings in Subtropical Taiwan. J. Asian Archit. Build. Eng. 2005, 4, 259-264. [CrossRef]

19. Cheng, C.-L.; Kawamura, S.; Chen, C.-J.; Liao, W.-J. Study on same-floor drain system as life-cycle maintenance solution in residential buildings. Archit. Sci. 2020, 22, 35-44.

20. Architectural Design Material 101 SI Housing; Architectural Thought Research Institute: Tokyo, Japan, 20 June 2005.

21. Technical Specification for Same-Floor Drainage Engineering in Buildings; (CJJ232-2016); AQSIQ, MOHRUD: Beijing, China, 2016.

22. Standard for Design of Building Water Supply and Drainage; (GB 50015-2019); China Planning: Beijing, China, 2016.

23. Chen, C.H. Apartment Planning E Design Regulations; CHAN'S ARCH-PUBLISHING CO., LTD: Taipei, Taiwan, 2016.

24. Dell'Isola, A.J.; Kirk, S.J. Life Cycle Coting for Design Professionals; McGraw-Hill: New York, NY, USA, 1982.

25. Yu, K.-H. Economic Life of Residential Buildings in Taipei City. Master's Thesis, National Taipei University of Department of Real Estate and Built Environment, Taipei, Taiwan, 2009.

26. Lee, C.-J.; Cheng, C.-L.; Liao, W.-J. The issues and application of same floor drain system in the building of social housing. In Proceedings of the CIB-W62 45th International Symposium, Melbourne, Australia, 7-10 September 2019. 